\title{
CONTESTED SITES OF MEMORY ON TARARA IN NEW
}

\section{ZEALAND}

Senka Božić-Vrbančić, Sveučilište u Zadru, svrbanci@unizd.hr

$10.31902 /$ fll.26.2019.6

UDK 930.85

\begin{abstract}
During the colonial time in New Zealand Maori and Croatians worked together on the gumfileds of the Far North. On the gumfields both Maori and Croats were stigmatized, each in their own way and for different reasons. This stigmatisation excluded them from the dominant culture and constituted the common terrain for their relationship. The intermarriages were common. This paper explores the ways the stories about Maori and Croatians in New Zealand have been narrated or represented in five different sites of memory, built in different historical time, from colonial New Zealand to the bicultural New Zealand of the present. It argues that a parallel reading of these sites shows that in between these sites, there seems to be a space where all of these gumfield stories are entangled, with motives that are embedded in social reality. Hence these stories reflect processes of differentiation and power relations in the social. Their meanings are constructed retroactively, the past they strive to embody is always presented in the form of tradition, but the meaning of tradition restructures and changes constantly with the political transformations of the social.
\end{abstract}

Keywords: Tarara identity, sites of memory, New Zealand.

\section{Introduction}

In the essay "Who Needs 'Identity'?", Stuart Hall (1996) argues that the question is a complicated one, given that the "natural" definition of identity presupposes that when we talk about identity we recognise that there is the stable core of the self which remains static across time, or, in other words, if we talk about cultural identity or group identity it seems to be "natural" to recognise a common origin, a shared history and ancestry held by people who belong to the particular group. In opposition to this essentialist, seemingly natural definition, which tries to fix the meaning of ethnic, racial and national conceptions, many contemporary scholars pointed out that the idea of "the stable core of the self," or the homogenic notion of identity actually masks the plurality of positions that exist behind each "identity." But, according to Hall, there is a complex relation between these two concepts. Inspired by Derrida's theory of deconstruction of binary relations, Hall argues that essentialist and antiessentialist concepts cannot be seen as "incorrect/correct" alternatives, one more adequate or truer 
than other; on the contrary, anti-essentialism cannot escape essentialist concepts since without them certain key questions cannot be thought. But, even though essentialist concepts cannot be completely replaced, they have to be put "under erasure" and "identity is such a concept - operating 'under erasure' in the interval between reversal and emergence" (Hall, 2).

In this paper I argue that claims of identity are always connected with the interplay of discourses, emerging within the exercise of power. The constitution of identities always involves the exclusion of certain possibilities, and thus identities are always about the marking of difference. They emerge through the relation to the Other, hence they are constantly destabilised by what is excluded in their production (Laclau 2000; Brah 2000). Their fullness is unachievable, they can never be closed, and as Hall puts it:

they are subject to a radical historicisation, and are constantly in the process of change and transformation [...]. Though they seem to invoke an origin in a historical past [...] actually identities are about questions of using the resources of history, language and culture in the process of becoming rather than being [...]. They arise from the narrativisation of the self, but the necessarily fictional nature of this process in no way undermines its discursive, material or political effectivity, even if the belongingness, the "suturing into the story" through which identities arise is, partly, in the imaginary (as well as the symbolic) and therefore, always partly constructed in fantasy, or at least within a fantasmic field (Hall, 4).

In other words the processes of identification rather than identity by itself underline the ways we narrate "who we are" and "who we were."

Here I explore the ways the stories about Maori and Croatians in New Zealand have been narrated or represented in five different sites of memory in New Zealand: the Matakohe museum, the Jurlina museum, Yelash Gumfields museum, the National Museum of New Zealand - Te Papa, and Tarara monument in Auckland. These two peoples, the Northern Maori tribes of Te Aupouri and Te Rarawa and Croatians from Dalmatia met in the gumfields of the Far North between 1880 and 1940. Croatians emigrated from Dalmatia which was then a part of the Austro-Hungarian Empire in search of jobs. The land of the Maori, due to colonization, had been confiscated or sold, and they were, like Croatians, in search of labour for wages. The gumfields of the Far North was the place of their encounter where they developed, what is today usually described as a "harmonious relationship" that was marked by a significant number of intermarriages.

To understand how narratives about Maori and Croats have been constructed, I analyse their production in specific historical sites at different times, 
from colonialism to the bicultural or multicultural New Zealand of the present day. Inspired by discourse theory, especially the work of Laclau, I analyse New Zealand social models - colonialism, assimilation, biculturalism or multiculturalism - as different nodal points, master signifiers that, each in its own way, partially fixed the meaning of the social. Nodal points bind together a particular system of meaning. All identities are in one way or another produced through nodal points and, consequently, they are "political entities that involve the construction of antagonisms and the exercise of power" (Howarth and Stavrakakis, 9). Today New Zealand presents itself as a bicultural country (Maori and Pakeha), where difference, or multicultural coexistence of different people is celebrated. But passing from colonialism to biculturalism cannot be understood as a story of progress, a story that sees the present simply as continuous with the past, an improvement on it; nor can it be analysed as a simple break with the past. This passing is based on social antagonisms, which presuppose the category of "dislocation." To paraphrase Laclau, antagonism is at the heart of all social identity. It is the limit of all objectivity, a denial of any closed system and this denial, this negativity, is constitutive and foundational, affecting and transforming identities of all the social groups involved (Laclau 1990, 17). The resolution of an antagonistic situation is always contingent, given that the signification of a particular position cannot be fixed in advance.

In short, for Laclau the social never manages to constitute itself as an objective order. It is structured around this impossibility, but it is precisely this impossibility of closure that makes new identifications possible. The presence of antagonisms in the social is witness to the ultimate impossibility of the social. The response to antagonism is the imaginary reconstitution of the negated identity (Laclau 1990, 211). And this reconstitution needs to be understood as produced in specific discursive formations and practices.

During the colonial time both Maori and Croats were dislocated in discrete ways. Colonisation made Dalmatia the most south-easterly part of the Austro-Hungarian Empire and New Zealand the most south-easterly part of the British Empire, their identities emerging in interaction against the Empires that contextualised their specific nationhood. In these sociohistorical contexts, Maori lost their land and gradually become incorporated into the European economy, resulting in local migration. Sometimes whole families, from different areas of New Zealand, travelled north to work as gumdiggers. At the same time, Austro-Hungarian policies impoverished numerous families and many Dalmatians emigrated in search of better lives and jobs. Through colonialism and global economic processes, they were simultaneously brought together on the gumfileds and marginalised. So the constitution of the gumfields cannot be understood as a local development. It was a complex interaction involving a macro-economy that led to this specific New Zealand industry. It was the global 
that constructed the local reality. Thus gumdiggers' immediate conditions and everyday existence were partly constituted in a global arena. Although situated in an isolated part of New Zealand gumdigging played a part in the transformation of New Zealand society. It reflected the contradictions and ambiguities in the cultural, political and economic politics of New Zealand identity.

\section{A Brief Outline of the Beginning of Kauri Gum Industry and Maori and Croatian Contacts in New Zealand}

The first contact between Europeans and the people of Aotearoa (Maori name for New Zealand) occurred in 1642 when the Dutchman, Abel Tasman and his crew arrived at Taitapu, 'Golden Bay'. Fighting broke out. Later, the Dutch named this "newly discovered" land Zeelandia Nova, 'New Zealand'. Nearly 130 years later, in 1769, Captain James Cook circumnavigated New Zealand. Cook calculated the population of New Zealand at 100,000. There is a lack of evidence about the population at that time but Metge (1971) states that the population was probably between 200,000 and 250,000 and most of this population was in the North Island. The people of Aotearoa used the word maori, which meant ordinary to "distinguish their own normality as a people from the exotic or alien newcomers" (Ballara, 42). They called Europeans pakeha after an ancient term for pale-skinned people "who had arrived from the sea, from outside Maori territories" (Salmond, 27). Maori saw the land as an ancestor, as a living entity. Land was a source of identity and status. Each tribe occupied certain part of the land and boundaries were known precisely. Some groups probably lived in permanent settlements but went occasionally to other parts of the land to exploit particular resources. Sometimes some groups lived on the lands of other people, using their resources such as trees or rivers. The use rights over the land did not confer a right to land. Occupation of land by conquest was common and meant that "land was occupied on the basis of unequal rights to it; the conquered who had lost their rights could squat on or be assigned land to cultivate by their conquerors or others; they did not own it, and commonly owed duty and tribute to those with mana over the land" (Ballara, 199).

After Cook's "discovery" of New Zealand other Europeans began to visit "the new land." The navigators were followed by whalers, sealers and traders. Contact with the traders brought change to Maori society. Guns become another element in Maori warfare. Some tribes were virtually exterminated in the musket wars of the early nineteenth century. Missionaries entered the world of the Maori in 1814. Before 1840 there were three missionary groups; the Anglicans, the Wesleyans and the Roman Catholics. All of them mirrored the societies from which they came. Their perception of "savages" who had not yet heard of God offered the potential for reform. In their minds Europeans were 
"civilised" and Maori were savages who according to evangelical and moral imperative needed to be "saved." They found some Maori cultural expressions (for example Maori mythology, their war dances and chants) abhorrent, something that was mostly described by epithets such as "diabolical", "demoniacal" and "evil." Mission stations mushroomed all around New Zealand, schools were established and "the mission Maoris were taught to read and write as well to cultivate the land" (Salmond, 21). In 1838 the New Zealand Land Company was constituted in England. The numbers of Europeans living permanently in New Zealand increased. According to Metge between 1830 and 1838 that number arose from 150 to over 2,000 (40). In 1840 the Treaty of Waitangi was signed by Lieutenant Governor William Hobson on behalf of the British government and by a number of Maori leaders. It gave to the Crown alone the right to acquire land from Maori. The Treaty was later passed around the country for further signatures. After the Treaty the land sale system began. British settlers saw unoccupied land as "waste land". But what appeared to them as "waste" or "empty" land was a land owned by Maori tribes. For Maori there was no "waste land" in "the sense of land which no one owned." Joseph Somes, the Governor of the New Zealand Company expressed his view of the "land rights" in a letter to Lord Stanley:

[In] those vast regions, which the early discoverers found occupied by scanty tribes of savages [...] people [...] had no idea of property in land according to our notions. Particular tribes claimed a right to exclude others from making use of their lands in their neighbourhood; and may be said to have possessed such right, as long as force or fraud gave them the power of checking intrusion. But of any individual rights in the soil [...] these people had no notion. The law of England rightly held that they could be held as possessing rights, of which they had not even formed a conception to themselves. What rights they enjoyed and used, the law acknowledged [...] But whatever was unoccupied, was held to be unappropriated; and to this the Crown asserted its right. This is the foundation of the rights of the Crown to the waste lands of its colonies (Somes quoted in Ballara, 34).

In 1865 the Native Land Court was established. Sales under the ten-owner system and individualised titles to land were introduced. Belich argues that the Native Land Court was designed to "destroy Maori communal land tenure and so both facilitate Pakeha land buying and 'detribalise' Maori" (258). Some Maori chiefs sold off land without consulting their people. Some of them were persuaded or forced to sell. By that time the basis of Maori society had changed. In 1857 some Maori tribes in the North Island elected a Maori King. Soon after 
the King Movment was established, war between Maori and Pakeha started in Taranaki. After the wars, European settlers moved more into the interior of the North Island, protected by the military settlers and the police (Belich 1996).

In 1867 the Maori were given four seats in Parliament and Native Schools (in English language) were established. The population balance had changed sharply in favour of Europeans during the wars of the sixties and by 1880 Pakehas predominated even in the North Island, where the Maori population was chiefly concentrated (Ballara, 72). By the turn of the century the Maori population had reached its lowest level. According to Belich the Maori population declined from "about 60,000 in 1858 to about 48,000 in 1874, and then to a nadir of about 42,000 in 1896, after which a steady rise began" (Belich, 249). This decline was the result of diseases (influenza, smallpox, whooping cough, measles, sexually transmitted diseases etc.), which were often fatal due to Maori having no immunity to these new diseases, considerably changed living conditions or standards, and political oppression (Ballara, 257). King argues that New Zealanders at that time "were in no sense the 'one people' ('he iwi tahi tatou') that Governer Hobson had proclaimed them to be at the signing of the Treaty of Waitangi in 1840" (285). Because of the decline in Maori population some Europeans believed that the Maori race was a dying race. It was about 1880s that Maori were entering paid employment, mainly as unskilled labourers. New economic opportunities caused migrations. Some Maori families established their own farms, but some of them travelled away from home to take wage employment. Sometimes whole families or hapu specialised in specific jobs and worked as seasonal labour, namely as goldminers, gumdiggers or on government roads and other public projects. Maori from many different areas travelled north, to work as gumdiggers, "staying there for months, sometimes years, in makeshift, temporary villages in order to earn a little money" (Ballara, 254).

Kauri gum is the fossilised resin of the massive kauri trees that once formed vast forests over the northern half of the North Island of New Zealand. In 1805, Europeans realised the commercial possibilities of kauri gum. In 1815 traders started to ship kauri gum to Australia, Britain and America but, as Smith has put it, they "asserted that they did not known (nor particularly cared) for what purpose the commodity was desired" (Hingley 1979). By the 1840s, it was known that kauri gum could be used for oil varnishes and a kind of "gum-rush" started in Northland. In those early years gum was easily found on or near the surface. As the surface gum became worked out, gumdiggers began to dig for it. Usually, the diggers used a gum spear to probe the ground and locate the gum. Firth points out that "for approximately the first twenty years [...] [gumdigging] was restricted almost solely to the Maoris, and the Europeans regarded it as an employment worthy only of natives" (15). Even though Maori worked hard on the gumfields they were seen by Europeans as lazy. 
By the end of the nineteenth century, the reputation of kauri gum was well established in the American and British markets and European immigrants were joining the Maori people in collecting gum. Gumfields attracted individuals from all around the world. Gumdiggers as a class were not respected in New Zealand. As Marshall points out

gumdigging was attractive to the misfit, the nonconformist, the recluse, the misogynist, the shiftless - in short to all those people most likely to arouse suspicion in a colonial society where the ethos of ruling groups placed high value on conformity, abstinence, industry, the stable family, and so forth. (1968: ii)

Any person who moved to the gumfields was held in general contempt and considered to have slipped to the bottom of the economic and social ladder. It was believed that the fields attracted the wild, the rowdy and the reckless. According to Mackay gumdiggers were "landless Maori men and women; transient, hard-living European men; dirt-poor migrants; and steady men, down on their luck in the long depression of the late nineteenth-century" (4). The expressions "He is a just a gumdigger" and "vagabond occupation" were common. Drunkenness amongst gumdiggers was common and it was harshly criticised in many colonial newspapers:

It is sad thing, and a great waste of human power, to see men toiling and labouring hard from daylight until far into the night for perhaps a month for the sake of three days or four days "spree," and so on, "da capo"; then delirium tremens two or three times, and the wretch dies as miserably as he has lived - unwept and unpitied (Weekly News, 29 May, 1869 p.9 B).

The culture of the gumdiggers' world was an exclusively male. In A Man's Country' Phillips (1987) portrays the world of the frontiers and specific male culture that was developed in New Zealand in the nineteenth and at the turn of twentieth century. It originates from Victorian Britain village society's division of labour in which the men carried out the jobs demanding great physical strength while women were occupied with domestic drudgery. Therefore the role of colonisation, of taming the distant wilderness was usually considered as man's mission. Thus the image of the ideal coloniser is shaped in the rural past of Victorian Britain: "the strong and the bold who go forth to subdue the wilderness and conquer new lands" (Phillips, 5). Being on the frontier of a new and strange environment men developed male culture: an appreciation of strenuous physical labour (where "loafers" and swaggers present the hated, and sometimes ridiculed opposite); mateship or comradeship as the mode of 
life; course language and swearing that could confuse "the new chum," outlets in the drunken spree as compensation for oppressive loneliness, contempt of women and suppression of "womanish nature." Gumdiggers, like goldminers, whalers, bush workers and other itinerary workers were included in the same type of male culture.

By 1900 more than 3,000 Croatians had settled on New Zealand gumfields. Most of the immigrants were men, and they came from only a few villages on several islands and from an area along the Central and Southern Dalmatian coastline, especially between Makarska and the Peljesac peninsula (Zivogosce, Drasnice, Drvenik, Podgora, Tucepi) from the offshore islands of Brac (Nerezisca, Selca, Blaca), Hvar (Sucuraj, Gdinj, Bogomolje) and Korcula (Zrnovo, Pupnat, Blato) and from the coastal hinterland with its centres Vrgorac and Imotski (Stoffel 1994). According to Stoffel the main reason for emigration from Croatia was poverty. It is important to stress that the political situation in Croatia at that time created poor economic conditions. Suppressed by Austrians and Hungarians, even in the 1900s many Croatians lived under a remnant of the old feudal system. The peasants were exploited financially with heavy taxes, monopolies on trade routes, and politically with discriminatory treatment and strict conscription terms. The Habsburgs contumeliously referred to their Slavic subjects as Volkersplitter "ethnic fragments." They were second class people with few rights and little hope of achieving any. It is not surprising that under those conditions people wanted to find a "better life" and "justice."

Croatians came to New Zealand during hard times, during an economic depression that lasted all through the 1880s and into the next decade. On gumfields Croatians lived and worked in groups. At the beginning they were presented as hardy, sober, industrious and law abiding people. They had a greater impact on the gumfields than any other group. According to Mitcalfe,

they were innovative and efficient, able to work systematically down through two or three levels of former forest, sometimes as deep as eight to ten metres, taking all the gum, even the chips. They invented sluices, gum-washing machines and new types of sieves. (Mitcalfe, 77)

But soon their efficiency was seen as a problem. In 1898 there was some fear that the "invasion of Croatians" would seriously affect the economic growth of the young British colony. They were blamed for everything, and even the dropping of prices was seen as a result of cheating by Croatians who offered a large quantity of gum on the market. In 1898 the Kauri Industry Bill was passed to reduce the number of Croatians in the gumfields. Premier R.J. Seddon, speaking in Parliament described them as "locust-like." Large areas of Crown land were reserved just for "the digger of British extraction" (Firth, 9). In 1908 and 1910 
other restrictive laws against Croatians, "aliens" on the gumfields, were passed, protecting interests of the British gumdiggers. Croatians were described in daily newspapers of the time as the "greatest pest," "like locusts," "herd of sheep," "squareheads," a "horde of barbarians," "white Chinamen," etc. Croatians gumdiggers who found themselves isolated, surrounded by unsympathetic and even hostile people discovered that social contact was easier with the Maori than with the Anglo- Saxon diggers. Mixed social gatherings between Maoris and Croatians became common and there were many intermarriages. Maori called Croatians Tarara, and some even claimed that the new tribe emerged, Tarara tribe.

To summarize, we can say that at the end of the nineteenth century, the New Zealand government sought to create the positive identity of the farmer as settler, against those who were seen as sojourners. And gumdiggers were archetypally sojourners. Their "roaming" way of life concerned many members of the elite in New Zealand, including members of Parliament. And so, they became an observed population that, together with their observers and the means of their observation, created specific tensions based on colonial discursive practices. Maori on the gumfields were under special surveillance. Although they had to work very hard, gumdigging was represented as an "easy choice" and consequently was seen as evidence that Maori were lazy and lacked industrious habits. These new truisms, in turn, justified the taking of Maori land: "land should shift from 'unproductive' Maori to productive 'Pakeha' possession" (Koning and Oliver 1993: 15).

Croatians on the gumfields were under surveillance, too. At that time, they worked in groups and were very productive. British gumdiggers, also drawn into the relation of the settler/sojourner frontier, created a new differentiation by reference to Croats on the gumfields who came to be seen as a "danger" for "legitimate" British gumdiggers. As "aliens" or "dangerous aliens" they found themselves with Maori, in the midst of a created site of observation, their normality and suitability to be incorporated into the colonial society under judgement. This normalising technology of the power of social quarantine on the gumfields originated from a binary divide that characterised every colonial society - "us" and "them." Accusing the other of being "dirty," "lazy" or "immoral" always implies the opposite, we are "clean," "industrious," "moral." As Hardt and Negri argue, the logic of binary division between "us" and "them" is always connected with the way "our" identity is constructed (127). The negative construction of the Other - they cannot control themselves, they do not understand the values of the civilised world, they are dirty - functions as an absolute negation, and, precisely because the difference of the Other is represented as absolute, it can be inverted to become the foundation of "the Self": 
What first appears strange, foreign, distant thus turns out to be very close and intimate. Knowing, seeing and even touching the colonised is essential [...]. The intimate struggle with the [colonised], feeling the sweat on its skin, smelling its odor, defines the vitality of the master. This intimacy, however, in no way blurs the division between two identities in struggle, but only makes more important that the boundaries and the purity of the identities be policed [...]. What first appeared as a simple logic of exclusion, then turns out to be a negative dialectic of recognition. The coloniser does not produce the colonised as negation, but, through a dialectical twist, that negative colonised identity is negated in turn to found the positive coloniser Self. (Hardt and Negri 127-128)

But this division in the social based on the difference between "us" and "them" never "breaks down neatly into an absolute binary between pure opposing forces". Reality always produces proliferating multiplicities. In this context of multiplicities we can read the stereotypes applied to Maori and Croats together - "Maori laziness" or "Croatian overindustrious habits" - each of these representations in its own way recognising the difference of the Other as a "threat" but, as Žižek puts it, the threat is internal, not external, hence we can say that "the Other is the Other in my interior" (201). The overriding binary opposition created the situation where it seemed "natural" to blame Maori and Croats, Others, for the misfortunes that colonisers were facing within the new colony. In other words, stories about Maori "laziness" or Croatian "animality" facilitated the colonisers' sense of strong identity and cultural homogeneity.

On the gumfields both Maori and Croats were stigmatised. This stigmatisation excluded them from the dominant culture and constituted the common terrain for their relationship.

\section{Gumfields as Sites of Memory}

During the 1950s, as gumdigging became less attractive, as prices slumped and new technologies rendered gum obsolete, the gumfields as a productive locale ceased to exist and the gumdigging way of life slowly shifted to museums and became part of New Zealand history. Remembering the past is crucial for our sense of collective identity, argues Lowenthal (197-213), hence collective memories are often embodied in books, museums, archives, cemeteries, monuments, anniversaries and so on. Nora calls these remnants of the past "sites of memory" (1996). Through these sites, society materialises its memory, but this materialisation or externalisation of memory is always partial given that the very materialisation of memory conceals something that should be suppressed or forgotten. In other words, there is no "pure," "clean" site of memory which does not suppress some other memories, some other stories. 
In the case of Maori and Croatian relationships on the gumfields, and for the purpose of this paper, I chose five sites of memory, four museums and one memorial that each in its own way tells and retells the story of kauri gumdigging: Matakohe Kauri Museum, the Jurlina museum, Yelash gumfield museum, the Museum of New Zealand - Te Papa, and Tarara monument.

Matakohe Kauri Museum was built in 1962, when the policy of assimilation was very strong in New Zealand. It was built as a memorial to the district's pioneers and (re)presents gumdigging as a part of the "heroic pioneering past" of British gumdiggers. The memory that is repressed is that gumdiggers as a class were not respected at all. The expressions "He is a just a gumdigger" and "vagabond occupation" were common in earlier times. The representation of Maori and Croatians who lived and worked in the region at that time, is limited to photographic collections in Matakohe. Their labels clearly present social relations of power constructed in colonial New Zealand (for example one photo is labelled: Allan McPherson, Dalmatian gumdiggers and Maori assistants). So, under the new master signifier, the policy of assimilation, this exhibition offered a singular vision of a highly romanticised past (New Zealand as a "working paradise" for British diggers), utilising different elements to tell its story, clearly displacing the memory of the past in order to paint a new picture of New Zealanders as "one happy nation," who worked very hard in order to build New Zealand.

The Jurlina museum is a private family museum, a former gumstore. It tells the story of Croatian gumdiggers. Even though its interior looks like a frozen past - the ledger books with numerous accounts and names of Croatian diggers, a few books written in Croatian, different gumdigging tools and glimmering pieces of kauri gum - the narratives which frame these objects are not frozen, they are in constant interplay with dominant discourses, creating memories of one particular marginal group in terms of their achievements and the establishment of the community (see Božić-Vrbančić 2008).

Yelash Gumfield museum, located on the top of Ahipara Hill, one of the last gumfields in New Zealand, extends its notion of a museum towards the landscape which surrounds it - deserted gumfields. So, not only the old gumdigging shack, but also the deserted land where once thousands of diggers worked has become a museum. The museum, sited partly on Maori land, is dedicated to Maori and Croatians, its narrative completely framed by resistance to British oppression.

In the Museum of New Zealand Te Papa Tongarewa, which opened in 1998 Maori culture is represented as tangata whenua - the indigenous culture of New Zealand, and Pakeha culture is defined as tangata tiriti - cultural identity developed by new settlers through their relationship with the land. The cultures of non-British minority groups are seen as a part of the multicultural heritages of new settlers. All together, these cultures make something new, a 
unique identity of New Zealand encapsulated in the slogan: "One nation, Two peoples, Many cultures." So, even though the presence of different minority groups is acknowledged, the main emphasis is put on the connection between British migrants' cultures with indigenous cultures (different Maori tribes), in the New Zealand context producing something unique in the world. Non-British migrants, with their different ethnic customs, are represented as enriching New Zealand society merely with their presence in New Zealand. Croatians were seen as one of the groups that enriched New Zealand society by working on the gumfields and later developing the wine industry. Those different forms of racism they experienced on the gumfields as well as their relationships with Maori are not mentioned at all. The past is remembered in a new way which ignores these "unpleasant" intrusions, presenting New Zealand social space as a harmonious coexistence of different groups of people.

In short, each museum presents the past, namely the gumdigging era, in a different way. Matakohe Kauri Museum's politics of display stress the role of gumdigging in the pioneering days by including it in the official history (the dominant discourse). The Jurlina family's gumstore museum strives to tell the story of the achievements of Croatian gumdiggers underlining the linear progress of the community, the Yelash Gumfield museum connects the gumdigging industry with the wider issues of colonization and positions of Maori in New Zealand, and the Museum of New Zealand, Te Papa, celebrates cultural difference of contemporary New Zealand where gumdigging story is represented as a story of peaceful coexistence of different groups of people. So, different discourses shape the politics of display in these museums and, certainly, visiting the past is not possible just through the one entrance. In short, all of these museums are sites of ongoing conflicts and negotiation of identities. A parallel reading of these sites shows that in between these sites, there seems to be a space where all of these kauri gum stories are entangled, with motives that are embedded in social reality. Hence these stories reflect processes of differentiation and power relations in the social. Their meanings are constructed retroactively, the past they strive to embody is always presented in the form of tradition, but the meaning of tradition changes constantly with the political transformations of the social. As Žižek puts it, "every historical rupture, every advent of a new master signifier, changes retroactively the meaning of all tradition, restructures the narration of the past, makes it readable in another, new way" (56).

In a way the new master signifier "biculturalism," new dominant discourses that celebrate the peaceful co-existence of different groups of people also reflect on the ways Maori and Croatians represent and celebrate their difference in contemporary New Zealand. The celebration of Tarara day, organised by Maori and Croats, serves as an illustration of this argument. Just few months after Te Papa was opened, Maori-Croatian descendants built a monument in 
Auckland to commemorate the close bonds established between these two peoples. Built in Henderson by the Waipareira Trust and the Croatian Cultural Society in Auckland, the monument celebrates multiculturalism on the margins. The celebration of the reunion parallels Te Papa's representation of different customs and cultures in New Zealand, emphasising their contribution to the cultural richness of New Zealand society. The dominant discourse of biculturalism that prescribes the celebration of hybridity and the coexistence of many different cultures shapes this "provincial festivity." Thus the collective memory of Maori-Croatian descendants is re-designed in this new context. The past is romanticised and statements like "we are similar cultures," "we are genetically compatible," "we laugh and cry in the same way," "the Maori-Tarara mix is the best mix you can imagine," "we intermarried because we had a preference for each other," hide the traumatic experiences of the past when both groups were stigmatised on the gumfields. My point is not that Maori and Croatian cultures are totally subjugated or that they do not exercise any influence on the creation of a dominant bicultural discourse of tolerance and celebration of diversity. On the contrary, bicultural policies are partly a response to ongoing Maori resistance, protests and the fight for justice. But I would stress that subordinate cultures are not always, as it is very often presumed, in open conflict with the dominant culture (see Brah 2000). Even though they are on the margins, Croatian-Maori are not excluded from the marketing whirlpool and very often they present their identity in line with the new politics of consumerism, as if, if we cannot sell our identity, it does not exist.

The Tarara Day celebration centred on food and folkloric performances. In one way we can say that contemporary Maori and Croatians were "selling" their ethnicity as a "spice or taste that can be consumed" (Ahmed, 2000; on eating and racism see Tompkins 2012). Ahmed stresses that cultural differences have become more and more part of consumerism in the contemporary, postmodern world; both the dominant and dominated are entangled in the celebration of diversity by offering or consuming those who are defined as culturally different (Ahmed, 2000). However, as Ahmed states, we need to remember that this consumerism of ethnic differences originates in power relations in the social. Indeed, the way difference is constituted within the interstices of socio-political and economic relations can be encapsulated by the processes of consuming, eating and digesting "ethnic food" as described by bell hooks, or, as Derrida notices, the whole problem of subjectivity as a central problem of the Western metaphysics could be outlined through the process of "eating." But my point here is that no-one can eat guilt, no-one can consume and digest the trauma of the past. 


\section{Conclusion}

In this paper I have tried to trace transformations in the representation of the identities of Maori and Croats on gumfields in relation to changing cultural, political and economic regulations, from colonial times to the multicultural New Zealand of the present. Laclau argues that identifications could be seen as failures of identity, and, given that totality always excludes something, neither individual nor collective identities can reach a stable point of a total completeness. Nevertheless, each society functions in such a way as to imply it were possible to reach this fullness. In Laclau's words, "although the fullness and universality of society is unachievable, its need does not disappear: it will always show itself through the presence of its absence" $(1996,53)$.

I would like to finish this conclusion in the same way as I opened this paper, with Hall's question "Who needs Identity"? My answer is short and simple - Everyone!, since the question of identity and past the past that relates to it is always a matter of considerable political and cultural significance, it opens issues of power relations, belonging as well as of being and becoming.

\section{Works Cited:}

Ahmed, Sara. Strange Encounters: Embodied Others in Post-Coloniality. London: Routledge, 2000.

Ballara, Angela. Iwi: The Dynamics of Maori Tribal Organisation from c. 1769 to c.1945. Wellington: Victoria University Press, 1998.

Belich, James. Making Peoples: A History of the New Zealanders from Polynesian Settlement to the End of the Nineteenth Century. Auckland: Penguin, 1996.

Božić-Vrbančić, Senka. Tarara: Croatians and Maori in New Zealand: Memory, Belonging, Identity. Otago University Press, 2008.

Brah, Avtar. The Scent of Memory: Strangers, Our Own and Others. In A. Brah and A. Coombes (eds), Hybridity and its Discontents: Politics, Science, Culture. London: Routledge, 2000, pp. 272-291.

Firth, Raymond. The Kauri Gum Industry: Some Economic Aspects.: MA thesis, Department of Anthropology, University of Auckland, 1922.

Hall, Stewart. Introduction: Who Needs 'Identity'? In S. Hall and P. Du Gay (eds), Questions of Cultural Identity. London: Sage, 1996.

Hardt, M. and A. Negri. Empire. Cambridge: Harvard University Press. 2000.

Hingley, Bert. Gumdiggers of the North. Wellington: A.W. Reed, 1979.

Howarth, David and Yanis Stavrakakis. Introducing Discourse Theory and Political Analysis. In D. Howarth, A. Norval and Y. Stavrakakis (eds), Discourse Theory and Political Analysis. Manchester: Manchester University Press, 2000, pp. 1-24. 
King, Michael. Between Two Worlds. In G.W. Rice (ed.), The Oxford History of New Zealand. Auckland: Oxford University Press, 1992, pp. 285-308.

Laclau, Ernesto. Structure, History and the Political. In J. Butler, E. Laclau and S. Žižek (eds), Contingency, Hegemony, Universality: Contemporary Dialogues on the Left. London: Verso, 2000, pp. 182-213.

Laclau, Ernesto. New Reflections on the Revolution of Our Time. London: Verso, 1990.

Lowenthal, David. The Past is a Foreign Country. Cambridge: Cambridge University Press, 1985.

Metge, Joan. 1971. The Maoris of New Zealand. London: Routledge \& Kegan Paul. Mitcalfe, Barry. Northland, New Zealand. Auckland: Coromandel Press. 1984.

Nora, Pierre. Realms of Memory: The Construction of the French Past. New York: Columbia University Press, 1996.

Phillips, James. A Man's Country? The Image of the Pakeha Male. Auckland: Penguin, 1987.

Salmond, Ann. 1991. Two Worlds: First Meetings between Maori and Europeans 1642-1772. Auckland: Viking.

Stoffel, Hans Peter. The Dalmatians and Their Language. In S.A. Wurm, P. Muhlhausler and D.T. Tyron (eds), Atlas of Languages for Intercultural Communications in the Pacific and Asian Regions. Berlin: Mouton de Gruyter, 1996, pp. 191-194.

Tompkins, Kyla. Racial Indigestion: Eating Bodies in the Nineteenth Century. NYU Press.

Žižek, Slavoj. Enjoy Your Nation as Yourself. In S. Žižek (ed.), Tarrying with the Negative: Kant Hegel and the Critique of Ideology. Durham: Duke University Press, 1993, pp. 201-286.

\section{PRIJEPORNA MJESTA SJEĆANJA: TARARE U NOVOM ZELANDU}

Mjesta sjećanja o Tararama u Novom Zelandu i njihova međusobna povezanost Maori i Hrvati u Novom Zelandu su radili zajedno na kopalištima kauri smole od 1880-ih do kraja te industrije početkom 1950-ih. Na kopalištima su obje grupe doživjele stigmatizaciju, svaka na svoj način i iz drugih razloga. Na određeni način ta stigmatizacija je omogućila temelj za stvaranje nove zajednice, maorsko-hrvatske zajednice koja je bila obilježena velikim brojem međusobnih vjenjčanja. Rad propituje mjesta sjećanja i različite načine na koje je priča o maorsko-hrvatskim vezama na kopalištima smole predstavljena. Mjesta sjećanja su područja kulturnog pregovaranja kroz koja različite priče pokušavaju izboriti svoje mijesto u povijesti.

Ključne riječi: mjesta sjećanja, Tarara, Novi Zeland. 